\title{
ВПЛИВ РОЗВИТКУ ІНФОРМАЦІЙНО-КОМУНІКАЦІНОЇ ІНФРАСТРУКТУРИ НА РІВЕНЬ КОРУПЦЇ̈
}

\author{
ВЛИЯНИЕ РАЗВИТИЯ ИНФОРМАЦИОННО-КОММУНИКАЦИОННОЙ \\ ИНФРАСТРУКТУРЫ \\ НА УРОВЕНЬ КОРРУПЦИИ
}

\section{THE INFLUENCE OF INFORMATION AND COMMUNICATION TECHNOLOGY INDUSTRY ON CORRUPTION LEVEL}

У роботі проаналізовано взаємозв'язок між розвитком інформаційнокомунікаційних технологій (ІКТ) та рівнем корупції в краӥні. Так, як тільки одна присутність IКТ в економіиі не сприятиме зменшенню корупиійного рівня, тому проведено аналіз на взаємозалежність між корупцією, ефективністю уряду та економічною ефективністю. У якості інформаційної бази, дослідження трунтується на використанні індексу розвитку IKT (IDI) та індекс рівня корупції (CPI). Емпіричний аналіз здійснено на основі даних узагальнених індексів для 125 краӥн світу за 2013 рік. Було створено регресійні моделі та аргументовано отримані результати. Аналіз статистичних даних показав, що розвиток IКТ має негативну кореляцію з рівнем корупиії в країні, який в свою чергу має негативну корелячію по відношенню до ефективності уряду та економічної ефективності. Узагальнено переваги розвитку IКT, а саме: ефективний розвиток IКТ інфраструктури може сприяти більшій прозорості урядового апарату та культурній відкритості, які $\epsilon$ передумовою для ведення конкурентоспроможного бізнесу в краӥні.

Ключові слова: інформаційно-комунікаційні технології, інфраструктура, корупція, електронний уряд, економічна ефективність.

В работе проанализирована взаимосвязь между развитием информационнокоммуникационных технологий (ИКТ) и уровнем коррупции в стране. Так, как только одно присутствие ИКТ в экономике не будет способствовать уменьшению коррупционного уровня, поэтому проведен анализ на взаимозависимость между коррупцией, эфффективностью правительства и экономической эффективностью. $B$ качестве информационной базы, исследования основывается на использованье индекса развития ИКТ (IDI) и индекса уровня коррупщии (CPI). Эмпирический анализ осуществлен на основе данных обобщенных индексов для 125 стран мира за 2013 год. Было создано регрессионные модели и аргументировано полученные результаты. Анализ статистических данных показал, что развитие ИКТ имеет отрищательную коррелячию с уровнем коррупции в стране, который в свою очередь имеет отрицательную корреляцию по отночению $к$ эффективности правительства и экономической эффективности. Обзор преимущества развития ИКТ, а именно: эффективное развитие ИКТ инфраструктуры может способствовать больщей прозрачности правительственного аппарата и культурной открытости, которые являются предпосылкой для ведения конкурентоспособного бизнеса в стране. 
Ключевые слова: информационно-коммуникационные технологии, инфраструктура, коррупция, электронное правительство, экономическая эффективность.

The paper analyses the relationship between the development of information and communication technologies (ICT) and the level of corruption in the country. Hence, just presence of the ICT in the economy would not reduce the level of corruption. In addition, the analysis the analysis of the relationship between corruption, government effectiveness and economic efficiency was done. As an information base, study based on the use of ICT Development Index (IDI) and the index of corruption (CPI). The empirical analysis has been made based on generalized indexes for 125 countries in 2013. Moreover, has been created regression models and has been made a conclusion of aggregated results. Analysis of the statistics shows that ICT development has a negative correlation with the level of corruption in the country, which in turn has a negative correlation with respect to government efficiency and economy efficiency. Furthermore, have been done an overview of the benefits of ICT development, for example, the effective development of ICT infrastructure may contribute to transparency and cultural openness that are appropriate for the conduction of a competitive business in the country.

Keywords: information and communication technology, infrastructure, corruption, egovernment, economic efficiency.

Вступ. На сьогоднішній день країни все більше приділяють увагу розвитку інформаційно-комунікаційної інфраструктури, так як це один із факторів зростання економічної системи, забезпечення конкурентоспроможності на міжнародному ринку, а також покращення політичного та соціального стану країни. Тому актуальним питанням сьогодення є визначення та аналіз ролі IКТ у становленні країни, як вони впливають на зміни, що необхідні для становлення розвиненої країни.

Розвиток інформаційно-комунікаційних технологій відіграє значну роль у повсякденному житті. Створення сервіс-орієнтованих додатків сприяло революційному розвитку сфери комунікацій. Дослідження показують, що IКТ створюють позитивний ефект щодо відкритості країни, що зменшує ймовірність корупції та збільшує шанси для уряду врегульовувати випадки хабарництва та відносної поведінки, а також створює ефект застереження до повторення корупції серед населення. Значним кроком може слугувати впровадження електронного уряду, який передбачає прозорість та відкритість урядової діяльності, що досить ускладнює створення корупційних схем.

Теоретичні та практичні аспекти формування методології та їхнього практичного застосування знаходять своє відображення у роботах із використанням математичних методів та прогнозування, таких науковців: Чароенсукмонгкол та Мокбель [1] у своєму дослідженні показали значний вплив корупції на економічний розвиток та політичну стабільність; Акчай [2] визначає корупцію, як зловживання державною владою для особистої користі; Колієр [3] вважає корупцію, як психологічним, так і економічним феноменом; Кастелс [4] характеризує IКТ, як рушійну силу, яка слугує для зменшення корупції через децентралізацію влади та інформацію; Крішан, Андерсен [5, 6] 
у свої роботі підтверджують, що впровадження та використання електронного уряду має прямий негативний вплив на корупцію.

Постановка завдання. Метою цієї статті є визначення, систематизація та економіко-математичний аналіз впливу розвитку ІКТ на рівень корупції в країнах світу, та взаємозалежність індексів політичної стабільності, економічної свободи, державної та економічної ефективності. Основним завданням даної статті є здійснення емпіричного аналізу статистичних даних країн світу та підтвердження чи заперечення наступних гіпотез.

Першою гіпотезою цієї статті зазначимо: зростання показників рівня ІКТ має негативну кореляцію до рівня корупції в країні. Також попередні дослідження показали, що високий рівень корупції має негативний ефект на економіку країни та зменшує рівень довіри населення до уряду. Високий рівень корупції призводить до створення тіньової економіки, яка підтримує ірраціональне використання державних фінансових ресурсів та подальшого впливу на ефективність державного апарату. Відповідно, друга гіпотеза складається з таких припущень:

- Показник рівня корупції в країні має негативну кореляцію 3 показником ефективності уряду.

- Показник рівня корупції в країні має негативну кореляцію 3 показником економічної ефективності.

Методологія. У даній статті використано методи порівняння та узагальнення, систематизації та синтезу, групування (при систематизації статистичних даних країн світу); статистичні та економіко-математичні (визначення кореляції ІКТ-сфери до основних індексів розвитку країн). Обрахунки здійснено за допомогою аналітичної програми STATA14. Дані взято для 125 країн за 2013 рік, відповідно до доступності індикаторів. Проведено лійний регресійний аналіз на основі розроблених математичних моделей відносно індексів в міжнародних рейтингах (CPI, IDI, PS, EO, EE).

Результати дослідження. Для здійснення емпіричного аналізу, у роботі було використано дані таких статистичних порталів: Transparency International [7], ITU [8], Global Finance [9] та EconomyPolitics [10]. У табл. 1, наведено основні індекси міжнародних рейтингів, та шкала їх вимірювання.

Таблиця 1

Пояснення та шкали визначення основних індексів аналізу*

\begin{tabular}{|l|l|}
\hline \multicolumn{1}{|c|}{ Індекс } & \multicolumn{1}{c|}{ Шкала } \\
\hline Індекс корупції (CPI) & $0-100(0-$ високий рівень, $100-$ низький $)$ \\
\hline Індекс розвитку IКТ (IDI) & $0-10(0-$ низький рівень, $10-$ високий $)$ \\
\hline Політична стабільність (PS) & $-2,5-2,5$ (сильно корумповано, слабо) \\
\hline Індекс економічної свободи (ЕО) & $0-100(0-$ закрита, 100 - відкрита) \\
\hline Економічна ефективність (EE) & $0-1$ (малоефективна, високоефективна) \\
\hline Ефективність уряду (GE) & $-2,5-2,5$ (малоефективна, високоефективна) \\
\hline
\end{tabular}


Країни займають місця у рейтингу відповідно до даних індексів. Розглянемо топ-10 країн за індексом корупції (табл. 2). У першій п'ятірці переважають скандинавські країни (Данія, Фінляндія, Швеція та Норвегія). У свою чергу це означає, що дані країни мають найменший показник рівня корупції у світі. Україна ж займає 119 місце із 125, тобто країна вважається сильно корумпованою.

Таблиця 2

Рейтинги країн за індексами в 2013 році*

\begin{tabular}{|l|c|c|c|c|c|c|c|c|c|c|c|c|}
\hline \multicolumn{1}{|c|}{ Країна } & № & CPI & № & IDI & № & PS & № & EO & № & EE & № & GE \\
\hline Данія & 1 & 91 & 1 & 8,86 & 21 & 0,95 & 9 & 76,1 & 5 & 0,854 & 3 & 1,97 \\
\hline Нова Зеландія & 2 & 91 & 18 & 7,82 & 1 & 1,45 & 4 & 81,4 & 4 & 0,864 & 9 & 1,75 \\
\hline Фінляндія & 3 & 89 & 8 & 8,31 & 3 & 1,36 & 16 & 74 & 7 & 0,842 & 1 & 2,17 \\
\hline Швеція & 4 & 89 & 3 & 8,67 & 11 & 1,13 & 18 & 72,9 & 9 & 0,837 & 4 & 1,89 \\
\hline Норвегія & 5 & 86 & 6 & 8,39 & 6 & 1,33 & 29 & 70,5 & 11 & 0,819 & 5 & 1,86 \\
\hline Сінгапур & 6 & 86 & 15 & 7,9 & 4 & 1,34 & 2 & 88 & 2 & 0,954 & 2 & 2,07 \\
\hline Швейцарія & 7 & 85 & 13 & 8,11 & 2 & 1,37 & 5 & 81 & 3 & 0,875 & 6 & 1,81 \\
\hline Нідерланди & 8 & 83 & 7 & 8,38 & 12 & 1,12 & 17 & 73,5 & 14 & 0,778 & 8 & 1,77 \\
\hline Австралія & 9 & 81 & 12 & 8,18 & 17 & 1,02 & 3 & 82,6 & 6 & 0,847 & 11 & 1,62 \\
\hline Канада & 10 & 81 & 20 & 7,62 & 16 & 1,03 & 6 & 79,4 & 10 & 0,836 & 7 & 1,77 \\
\hline Україна & 119 & 25 & 64 & 5,15 & 99 & $-0,76$ & 121 & 46,3 & 101 & 0,313 & 101 & $-0,65$ \\
\hline
\end{tabular}

*Джерело: згруповано автором на основі $[7,8,9,10]$

Розглядаючи інші індекси, можемо зазначити, що наведені країни мають достатньо прозорий апарат управління та високий показник рівня ефективності економіки та розвитку інформаційних технлогій, так як спостерігаємо наявність цих країн в першій двадцятці.

У табл. 3 відображено розраховану кореляцію між різними показниками, які впливають на ступінь корупції в країні.

Таблиця 3

Кореляційна матриця*

\begin{tabular}{|l|l|l|l|l|l|l|}
\hline & CPI & IDI & PS & EO & EE & GE \\
\hline CPI & 1.0000 & & & & & \\
\hline IDI & 0.7952 & 1.0000 & & & & \\
\hline PS & 0.7744 & 0.6658 & 1.0000 & & & \\
\hline EO & 0.7910 & 0.6778 & 0.6305 & 1.0000 & & \\
\hline EE & 0.8582 & 0.8574 & 0.6466 & 0.8950 & 1.0000 & \\
\hline GE & 0.9154 & 0.8153 & 0.7615 & 0.7837 & 0.8768 & 1.0000 \\
\hline
\end{tabular}

*Джерело: розраховано автором на основі $[7,8,9,10]$ 
Дана кореляційна матриця відображає лінійний взаємовплив, який виникає між рівнем корупції та іншими показниками країни. Індекси GE та EE мають суттєвий прямий зв'язок з CPI, в той час, як IDI також показує значний рівень взаємовпливу з індексом корупції. Така кореляція може бути пояснена тим, що обидва показника (GE, EE) включать в себе аспекти інфраструктури, освіти та охорони здоров'я, також економічна ефективність - це основна мета ефективного уряду. Для перевірки другої гіпотези, пропонуємо розглянути результати регресійної моделі в табл. 4:

$$
C P I=\alpha_{0}+\alpha_{1} I D I+\alpha_{2} P S+\alpha_{3} E O
$$

Таблиця 4

Результати регресійної моделі №1

\begin{tabular}{|c|c|c|}
\hline CPI & Coeff. Estimate & $\mathrm{p}>|\mathrm{t}|$ \\
\hline IDI & 2.9775677 & 0.000 \\
\hline PS & 7.163141 & 0.000 \\
\hline EO & 0.6910736 & 0.000 \\
\hline Adj. R-squared & \multicolumn{2}{|c|}{$79.74 \%$} \\
\hline
\end{tabular}

Дані результати відображають залежну змінну CPI та вплив на неї таких індексів, як IDI, PS та EO. 3 отриманих результатів можемо зробити висновок, що вплив IDI $\epsilon$ негативним, адже коли значення індексу CPI сягає вищого значення, то означає менший рівень корупції,. Тому зазначимо, що при зростанні рівня розвитку ІКТ в країні, рівень корупції в свою чергу зменшується. Також відзначимо, що політична стабільність та рівень економічної свободи також значно впливає на рівень корупції. Значення «Adj. R-squared» пропонує показник передбачення змінних, які можуть пояснити 79,74 \% кореляції до CPI.

Для підтвердження припущень до другої гіпотези, пропонуємо наступні регресійні результати в табл. 5 за допомогою таких рівнянь:

$$
\begin{aligned}
& G E=\alpha_{0}+\alpha_{1} C P I \\
& E E=\alpha_{0}+\alpha_{1} C P I
\end{aligned}
$$

Таблиця 5

Результати регресійної моделі №2 та №3

\begin{tabular}{|l|c|c|c|c|}
\hline & \multicolumn{2}{|c|}{ Рівняння (2) } & \multicolumn{2}{c|}{ Рівняння (3) } \\
\hline \multicolumn{1}{|c|}{ GE/ EE } & Coeff. Estimate & $\mathrm{p}>|\mathrm{t}|$ & Coeff. Estimate & $\mathrm{p}>|\mathrm{t}|$ \\
\hline CPI & 0,0442255 & 0,0000 & 0,0090444 & 0,0000 \\
\hline R-squared & \multicolumn{2}{|c|}{$73,65 \%$} & \multicolumn{2}{c|}{$83,79 \%$} \\
\hline
\end{tabular}

Відповідно до отриманих результатів, можемо сказати, що GE та EE суттєво впливають на визначення рівня корупції в країні. Тобто, низький 
рівень корупції сприятиме підвищенню ефективності уряду та економічній ефективності, цим самим підтверджуючи зазначені припущення на початку. Подані вище показники, GE та ЕE, мають досить сильну кореляцію, а також їх взаємозв'язок із корупцією, пояснюється тим, що країни з більш ефективним урядом, як правило, досягають вищих показників рівня економічного зростання. Тому, якщо уряд має високий показник ефективності, то він: сприяє отриманню кращих кредитних рейтингів, в свою чергу це призводить до збільшення кількості залучення додаткових інвестицій, пропонуючи більш високу якість державних послуг і підвищуючи рівень накопичення людського капіталу. Завдяки допомозі іноземних ресурсів та ефектинового розподілу їх використання, підвищенню продуктивності державних витрат, а також прискоренню впровадження та використання технологічних інновацій створюється прозорий апарат управління, який заохочує нових інвесторів до вкладів капіталу в країні, розвику бізнесу та становлення розвиненої країни. Як наслідок, всі зазначені вище аспекти можливі у випадку зменшення рівня корпуції та усунення тіньових схем в уряді та економіці.

Висновки. Можемо зазначити, що попередній аналіз взаємозв'язку рівня розвитку ІКТ і рівня корупції в країні підтвердив очікування економетричними результатами. Використаний у роботі IDI індекс є більш збалансованим і зміг надати суттєві результати. Наукову новизну становить математично-змодельований взаємовплив факторів розвитку та зростання країни. Статистика 125 країн світу дозволила через мультирегресійний аналіз отримати результати, які доводять, що чим вищий рівень розвитку IКТ в країні, тим менший рівень корупції в ній. Математична модель пояснює майже 80 \% варіантів корупції у різних країнах, а корупція всередині країни пояснює майже $74 \%$ та $84 \%$ варіацій щодо економічної та урядової ефективності. Подальші наукові розробки доцільно здійснити щодо детального аналізу країн, що розвиваються за допомогою первинних статистичних даних, задля пояснення причин неспроможності переходу до розвинених країн.

\section{Література:}

1. Charoensukmongkol P. Does Investment in ICT Curb or Create More Corruption? A CrossCountry Analysis [Електронний ресурс] / P. Charoensukmongkol, M. Moqbel - Режим доступу до ресурсу: http://www.researchgate.net/publication/257639879_Does_Investment_in_ICT_Curb_or_Creat e_More_Corruption_A_Cross-Country_Analysis.

2. Akçay S. Corruption and human development [Електронний ресурс] / Akçay - Режим доступу до ресурсу: http://object.cato.org/sites/cato.org/files/serials/files/catojournal/2006/1/cj26n1-2.pdf.

3. Collier M. W. Explaining corruption: An institutional choice approach [Електронний ресурс] / Collier - Режим $\quad$ доступу до ресурсу: http://link.springer.com/article/10.1023/A:1019802614530. 
4. Castells M. Materials for an exploratory theory of the network society [Електронний ресурс] / Castells - Режим доступу до ресурсу: http://onlinelibrary.wiley.com/doi/10.1111/j.14684446.2000.00005.x/abstract.

5. Krishnan S. Examining the Relationships among E-Government Maturity, Corruption, Economic Prosperity and Environmental Degradation: A Cross-Country Analysis [Електронний ресурс] / S. Krishnan, T. H. Teo, V. G. Lim - Режим доступу до ресурсу: http://www.sciencedirect.com/science/article/pii/S037872061300075X.

6. Andersen T. B. E-Government as an anti-corruption strategy [Електронний ресурс] / Andersen - Режим доступу до ресурсу: http://www.sciencedirect.com/science/article/pii/S2212567115000854.

7. Corruption Perception Index [Електронний ресурс] // Official site Transparency International - Режим доступу до ресурсу: http://www.transparency.org/cpi2014/results\#myAnchor1.

8. Measuring the Information Society Report 2014 [Електронний ресурс] // Official site International Communicational Union (ITU) - Режим доступу до ресурсу: https://www.itu.int/en/ITU-

D/Statistics/Documents/publications/mis2014/MIS2014_without_Annex_4.pdf.

9. Economic Freedom by Country [Електронний ресурс] // Official site Global Finance Режим доступу до ресурсу: https://www.gfmag.com/global-data/economic-data/economicfreedom-by-country.

10. Efficiency Index [Електронний pecypc] // Official site EconomyPolitics - Режим доступу до pecypcy: http://www.economypolitics.com/p/economic-efficiency-index.html. 